Dubos, R. J. \& Schaedler, R. W. (1960). \%. exp. Med. III, 407.

Eyssen, H. \& de Somer, P. (1963). F. exp. Med. 117, 127.

Eyssen, H. \& de Somer, P. (1965). Ernährungsforschung ro, 264.

Gordon, H. A. \& Bruckner-Kardoss, E. (I96r). Acta anat. 44, 2 ro.

Heneghan, J. B. (I963). Am. 7. Physiol. 205, 417.

Huhtanen, C. H. \& Pensack, J. M. (1964). Poult. Sci. 43, 133 I.

Kenworthy, R. \& Allen, W. D. (1966). F. comp. Path. 76, 291.

Kenworthy, R. \& Crabb, W. E. (1963). \%. comp. Path. 73, 215.

Larson, N. L. \& Hill, E. G. (1960). F. Bact. 80, 188.

Leblond, C. P. \& Stevens, C. E. (1948). Anat. Rec. Ioo, 357.

Lipkin, M. (1965). Fedn Proc. Fedn Am. Socs exp. Biol. 24, Part 1, p. ro.

Michel, M. C. (1962). Amino Acides 5, I 57.

Padykula, H. A., Strauss, E. W., Ladman, A. J. \& Gardner, F. H. (196r). Gastroenterology 40, 735.

Shiner, M. (1957). F. Mt. Sinai Hosp. 24, 273.

Shiner, M. \& Doniach, I. (rg60), Gastroenterology 38, 419.

Verzár, F. \& McDougall, E. J. (1936). Absorption from the Intestine. London, New York and Toronto: Longmans, Green and Co.

\title{
Absorption of proteins
}

\section{By R. B. Fisher, Department of Biochemistry, University of Edinburgh}

Some years ago I reviewed current beliefs concerning the digestion and absorption of protein (Fisher, I954). The view then was that proteins were broken down to amino acids in the intestine and were passed across the mucosa as such into the portal blood.

There seemed to me to be two major objections to this view. The first objection was that all available evidence suggested that the time-course of hydrolysis of protein by alimentary enzymes was at least an order too slow. The second objection was that no one had ever accounted for more than a minority of the protein in the form of amino acids added to the blood stream.

Since that time a great deal of work has been carried out on a number of aspects of these problems. Before I consider how far this work has changed the position I want to try to clear up some general points.

First I want to emphasize the distinction between the two processes ( $I$ ) uptake of substances from the lumen of the intestine and (2) passage of substances from the mucosa into the body fluids. We have got so tied up with the notion that demonstration of active transport requires that we should show transport against a concentration gradient, that we tend to forget that what comes out may be in a different form from what goes in. For instance, when fructose is absorbed from guinea-pig small intestine, a third of it appears on the other side as glucose (Darlington \& Quastel, I953).

Secondly, I want to emphasize the potential multiplicity of means of transport. This is again best illustrated by the facts of carbohydrate absorption. None of us has any doubt of the existence of active absorption of glucose from the intestine. Neither do we doubt the existence in pancreatic secretions of enzymes capable of breaking down starch all the way to glucose. But it is now quite clear from the work 
of Chain, Mansford \& Pocchiari (1960) that maitose and higher oligosaccharides are absorbed from the intestine more rapidly than can be accounted for by their hydrolysis to glucose in the lumen. There must be means of transport of oligosaccharides as well as of glucose.

These examples should make it clear that the demonstration by various workers that there are selective mechanisms for absorption of amino acids from the small intestine does not solve all the problems. It does not exclude the possibility that more complex molecules can also be absorbed, and it does not tell us the form in which the absorbed material is passed into the body fluids.

Various workers have made attempts to examine the possibility that the products of protein digestion may be absorbed from the intestine in the form of peptides. This is very difficult to do satisfactorily. There are 400 possible dipeptides of dietary amino acids and 8000 possible tripeptides. The three full-scale papers that $I$ have consulted (Agar, Hird \& Sidhu, I954; Newey \& Smyth, I 959; Wiggans \& Johnston, I959) concern themselves with six dipeptides and one tripeptide.

The peptides so far investigated cannot be regarded as entirely a representative collection. They are:

$\begin{array}{ll}\text { GLY-GLY } & \text { ALA-PhAL } \\ \text { GLY-LEU } & \text { LEU-GLY } \\ \text { GLY-TYR } & \text { LEU-TYR }\end{array}$

$$
\begin{gathered}
\text { GLY-GLY-GLY } \\
\text { GLY-GLY-GLY-GLY }
\end{gathered}
$$

Whilst one recognizes the difficulty inherent in extending the range, it does seem that if some evidence of peptide absorption has been found, as it has, among this small sample, then peptide absorption may still prove to make an important contribution to uptake of the products of digestion from the intestine.

Before going on, the point should be made that it is not necessary, or even relevant, that peptide should be found in the tissue fluid in order that one should be able to claim that peptide is absorbed from the intestine. If it could be shown that a peptide left the intestinal lumen more rapidly than did an equimolar mixture of its constituent amino acids, we should have proof of peptide absorption, whatever appeared on the other side of the mucosa.

I still think that no one has shown that there is time for digestion in the small intestine. Crane \& Neuberger (1960) show a striking similarity between the rate of excretion of labelled urinary ammonia after feeding labelled protein and the corresponding rate after feeding a hydrolysate. Although they show that a mixture of trypsin and chymotryspin, in concentrations which can be taken to be reasonably physiological, can render a high proportion of their yeast protein soluble in trichloroacetic acid in a very few minutes, it is quite clear that this does not imply breakdown to amino acids. In fact the experience of these workers in preparing an enzymic hydrolysate of their protein for absorption studies indicates that after several weeks of incubation with a global mixture of pancreatic peptidases at a $\mathrm{pH}(8 \cdot 2)$ far more favourable to the peptidases than that in the duodenum, which is nearer 
to $\mathrm{pH} 6$ (Borgström, Dahlquist, Lundh \& Sjövall, I957), one-third of the peptide bonds are still not split.

However, this is really a side-line. People have supposed that protein was completely split to amino acids in the intestine, and have taken it that it was reasonable that it should be absorbed in this form and passed across into the tissue fluids in this form. Even if it were not absorbed from the lumen as amino acids it would still be reasonable that it could enter the body fluids as amino acids, and the reasonableness of this appears to be attested to by the plentiful evidence that there is an increase in amino acid concentration in the blood during absorption of a protein meal.

But is it really reasonable to suppose that all the products of protein absorption should be presented to the liver promptly in the form best fitted for deamination? And is there any good evidence that the protein absorbed can be accounted for by amino acids added to the blood?

I cannot answer the first of these questions in any rigorous fashion. But it was the unlikeliness of anything of this sort of thing that first directed my attention to this problem.

So far as the second question is concerned, there are two important investigations, that of Dent \& Schilling (1949) and that of Dawson \& Porter (1962). We need say little about the earlier investigation. In order to get anything quantitative out of the work a number of uncertain approximations had to be made, and the best guess that could be extracted was that amino nitrogen corresponding to some $30 \%$ of that fed could have been added to the blood stream during absorption of a protein meal by the dogs used.

Dawson \& Porter used ${ }^{14} \mathrm{C}$-labelled protein and they measured the increase in ${ }^{14} \mathrm{C}$ in the amino acid fractions of plasma and erythrocytes in the portal and systemic blood of rats during absorption of this protein. Their results led them to conclude that approximately $40 \%$ of the protein fed had been carried away from the intestine as amino acids.

Both these estimates must be excessive, because they do not make allowance for passage of endogenous protein into the intestine. There is no doubt that in Dawson \& Porter's experiments a great deal of amino acid of endogenous origin accompanied the products of absorption of the labelled protein into the blood stream. These workers measured the total amino acid concentrations in portal and systemic blood at intervals during absorption and one can calculate from these figures that the total amino acid added to the blood during the $6 \mathrm{~h}$ period of study corresponded to more than ten times the amount of labelled protein fed. The observations of Junqueira, Hirsch \& Rothschild (1955) on the appearance of ${ }^{14} \mathrm{C}$ in rat pancreatic juice protein after injection of $\left[{ }^{14} \mathrm{C}\right]$ glycine are sufficient to show that absorbed labelled material must have been passing back into the intestine in substantial amounts during much of this period. In view of the fact that the rate of addition of endogenous amino acids to the blood very much exceeded the rate of addition of exogenous amino acids in the conditions of the experiments of Dawson \& Porter, it is clear that a very small extent of incorporation of label into the endogenous protein entering the intestine could produce a large proportionate increase in the 
rate of addition of labelled amino acid to the blood stream. It seems quite possible that their estimate that $40 \%$ of the protein was absorbed into the blood stream as amino acids may be at least twice too high.

In any event, neither study has been able to account for as much as half the protein fed, and neither study has been able to make proper allowance for endogenous protein, so it seems inescapable that the majority of protein ingested by mouth does not pass into the blood stream as amino acids.

We are therefore in the position that no one can substantiate a claim to the establishment of the path by which two-thirds or more of dietary protein enters the body.

In these circumstances one may as well speculate. The one channel of entry which has not been properly studied is the lymphatic pathway. In some incidental observations made during the course of a study of the effect of fat on lymph flow Simmonds (1955) obtained values from which the total protein in the lymph could be estimated during absorption of meals of milk powder. It is quite clear from these experiments that the rate of protein transport increased substantially during absorption, but it is impossible to interpret the results because the size and contribution of the hepatic component could not be estimated.

Subsequently Morris (1956) made extensive observations in cats on the specific activity of plasma protein, hepatic ly mph protein and intestinal lymph protein following injection of ${ }^{131} \mathrm{I}$-labelled plasma protein or of Evans Blue. In these experiments the regular feature was that the specific activity of the intestinal lymph protein reached a maximum value before it attained the same specific activity as that of the plasma protein. If plasma protein were the sole precursor of intestinal lymph protein, the intestinal lymph protein should reach its maximum specific activity at the time when its specific activity is equal to that of the plasma protein. In other words, it should conform to the precursor-product relation established by Zilversmit, Entenman, Fishler \& Chaikoff $\left(194^{2}-3\right)$. The relation which is actually observed implies that a fraction of the protein in the lymph is unlabelled material, i.e. that it is of local origin. Unfortunately we know nothing of the nutritional state of the experimental animals, though they were anaesthetized and therefore presumably postabsorptive.

Thus there is some indication that the intestine can contribute protein to the body fluids by way of the lymph but there is little indication what kind of protein this is and there is also little indication of the rate at which it can be contributed.

Dawson \& Porter (I962) made some observations on the appearance of ${ }^{14} \mathrm{C}$ in mesenteric lymph obtained from cats $3-4 \mathrm{~h}$ after feeding with labelled protein. They concluded from single observations at this late time that very little of the absorbed protein was being transported into the body as protein in lymph. It is not at all clear that the lymph analysed was fairly sampled. Dawson $\&$ Porter report that $5 \mathrm{ml}$ could readily be withdrawn with a syringe if the intestine was gently manipulated. On the other hand, they base their calculations on the assumption that the normal rate of mesenteric lymph production is about $1.5 \mathrm{ml}$ per $\mathrm{kg}$ per $\mathrm{h}$, which would be of the order of $5 \mathrm{ml} / \mathrm{h}$ per animal. It is not clear therefore where the $5 \mathrm{ml}$ 
samples came from, and it is still open to question whether much of the volume and of the protein was not of adventitious origin.

All that one can say in conclusion is that the form in which the products of protein digestion enter the body is still not established. No one has been able to to show that more than a minority of it enters the blood stream as amino acids. It seems unlikely that more than a very little passes in through the lymphatics as amino acids. It is certainly not established that the amount of protein that can be secreted into the lymphatics by the intestinal mucosa is sufficient to make up the difference. But enough work has not yet been done to resolve the question. The crucial experiments in this field are very difficult to design and execute. But they are still worth doing.

\title{
REFERENCES
}

Agar, W. T., Hird, F. J. R. \& Sidhu, G. S. (1954). F. Physiol., Lond. 121, 25.

Borgström, B., Dahlqvist, A., Lundh, G. \& Sjövall, J. (1957). F. clin. Invest. 36, I 52 r.

Chain, E. B., Mansford, K. R. L. \& Pocchiari, F. (1960). F. Physiol., Lond. 154, 39.

Crane, C. W. \& Neuberger, A. (I 960). Biochem. F. 74, 3 I 3 .

Darlington, W. A. \& Quastel, J. H. (1953). Archs Biochem. Biophys. 43, I 94.

Dawson, R. \& Porter, J. W. G. (г962). Br. F. Nutr. 16, 27.

Dent, C. E. \& Schilling, J. A. (1949). Biochem. F. 44, 318.

Fisher, R. B. (1954). Protein Metabolism. London: Methuen \& Co. Ltd.

Junqueira, L. C. U., Hirsch, G. C. \& Rothschild, H. A. (I955). Biochem. Y. 6r, 275.

Morris, B. (1956). Q. fl exp. Physiol. 4r, 326.

Newey, H. \& Smyth, D. H. (1959). F. Physiol., Lond. 145, 48.

Simmonds, W. J. (1955). Aust. F. exp. Biol. med. Sci. 33, 305.

Wiggans, D. S. \& Johnston, J. M. (1959). Biochim. biophys. Acta 32, 69.

Zilversmit, D. B., Entenman, C., Fishler, M. C. \& Chaikoff, I. L. (1942-3). F. gen. Physiol. $26,333$.

\section{Recent studies on carbohydrate absorption}

\author{
By K. R. L. MANsford, MRC Metabolic Reactions Research Unit, \\ Biochemistry Department, Imperial College, London, $\mathrm{SW}_{7}$
}

In recent years, studies on the intestinal absorption of carbohydrates have tended to fall into one of two categories, (a) the mechanism of active sugar transport and (b) the absorption of disaccharides. In the first it is necessary to consider sugar transport in the intestine as a phenomenon closely linked with electrolyte and water absorption on the one hand and on the other with active transport processes in general. As these aspects are discussed in other contributions to this Symposium, this review is concerned with disaccharide absorption.

In the last decade, by a remarkable 'cross-fertilization' of interests, biochemists, nutritionists, physiologists, histologists and clinicians have combined to elucidate the localization and mechanism of disaccharide absorption and to explain in biochemical terms the clinical findings concerning human disaccharide intolerance.

As early as I90I, Waymouth Reid suggested that maltose may be absorbed intact at appreciable rates from the lumen of the small intestine (Reid, I901). Starling (I 906) drew attention to the fact that the hydrolytic activity of the intestinal contents 